\title{
Ovarian Thecoma
}

National Cancer Institute

\section{Source}

National Cancer Institute. Ovarian Thecoma. NCI Thesaurus. Code C66989.

A stromal tumor that arises from the ovary and is characterized by the presence of cells that contain lipid and resemble theca cells. The vast majority of cases are benign. 